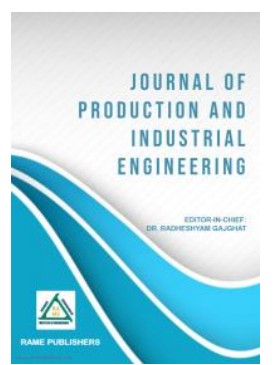

V. Sivamaran sivamaranv@gmail.com

S Azaruddin shaikazaruddin93@gmail.com

K Sivaprasad sivakotte552@gmail.com

K Ravikumar

kalasapatiravikumar@gmail.com

V Manoj Kumar mannum600@gmail.com

Department of Mechanical Engineering,

Audisankara College of Engineering \& Technology, Gudur, Andhra Pradesh. India

\title{
A Short Review on Applications of Aluminium Composites: Automotive, Aerospace and aircraft, Rail transport, and Marine transport industry
}

Abstract - Al MMCs presents an extraordinary chance and a large group of opportunities for the materials/plan engineer. There are presently numerous opportunities for control of properties/property mixes to suit explicit necessities of material and part properties to improve execution and dependability. New and arising mechanical improvements highlight the increment of use of $\mathrm{Al} \mathrm{MMCs} \mathrm{in} \mathrm{current} \mathrm{and} \mathrm{future} \mathrm{modern} \mathrm{turns} \mathrm{of} \mathrm{events.} \mathrm{A} \mathrm{portion} \mathrm{of} \mathrm{the}$ current boundaries and difficulties are being addressed through different R\&D endeavors to track down an enduring arrangement. From the front-going survey, it is clear that the eventual fate of $\mathrm{Al}$ MMCs in different modern and business applications is exceptionally brilliant. Progressed innovative improvements in essential and auxiliary handling of Al MMCs will keep on giving them a strategic advantage over the elective materials like $\mathrm{Mg}$, AHSS, and polymer composites. The fundamental difficulties and obstructions that have been recognized incorporate the absence of property displaying (particularly the high-temperature conduct of $\mathrm{Al}$ MMCs), absence of plan information, and significant expenses of essential and auxiliary cycles. Be that as it may, there are promising indications of mechanical leap forward by different examination endeavours committed to tracking down answers for these difficulties. New advancements in CNT and nanotechnology have, for instance, offered potential outcomes of the creation of $\mathrm{Al}$ MMCs with upgraded properties for high-temperature applications and further developed wear and erosion opposition. These amalgams offer new R\&D openings for additional improvement of Al MMCs and will rethink the new jobs and capability of Al MMCs in-car applications. Different specialists are likewise thinking of inventive expense decrease procedures to cut down the expense of supplanting customary ferrous materials with aluminum metal framework composites.

Keywords - Aluminium matrix, Automobile, Aerospace, Space applications, Casting process.

\section{INTRODUCTION}

In industries, they use several materials which are

Review Article - Peer Reviewed

Published online - 31 December 2021

(C) 2021 RAME Publishers

This is an open access article under the CC BY 4.0 International License https://creativecommons.org/licenses/by/4.0/

Cite this article - V. Sivamaran, S Azaruddin, K Sivaprasad, K Ravikumar, V Manoj Kumar, "A Short Review on Applications of Aluminium Composites: Automotive, Aerospace and aircraft, Rail transport, and Marine transport industry", Journal of Production and Industrial Engineering, RAME Publishers, vol. 2, issue 2, pp. 36-42, 2021.

https://doi.org/10.26706/jpie.2.2.20211202 having strength, less weight and should be available at a cheaper rate [1]. Aluminium (al) is most abundant elements on earth and it is available at very low cost. The products which are manufactured by using the aluminium alloy are having low cost and with low density (see table 1) [2]. Aluminium is not only used in the manufacturing process but also in the manufacturing of house hold particles and some of the products are also used in the constructional purposes. When the technology increases it also used to understand that the aluminium is mainly used in the industrial purposes. The properties of aluminium are: less 
weight, good thermal/electrical conduction, exhibits greater strength, resistance to corrosion. [3]. Compare to other metals and their performances aluminium has greater performance and composition than the other metals. The choice of aluminium alloys and composites derives from one important attribute of aluminium metal-light-weight.

In Automobile ventures, the parts which are fabricated by aluminum have less weight, lower fuel utilization, lower emanations, expanded payload (for travellers and freight), and are simpler to take care of. On account of the aviation and airplane industry, it presents more payload (freight), less fuel, and lower discharges. The benefits in which the aluminium is utilized are marine, rail, bundling, warm administration, building and development, sports, and entertainment.

Aluminum has a decent electrical and warm conductivity has seen its expanded use in electrical conduits, electronic bundling, and warm administration. These days, aluminum is a significant material for energy preservation and ecological insurance $[4,5]$. Metal framework composites (MMCs) are metals or metal compounds that consolidate particles, stubbles, filaments, or empty miniature inflatables made of an alternate material and proposition remarkable freedoms to tailor materials for the particular plan process $[6,7]$.

TABLE 1

PROPERTIES OF ALUMINIUM ALLOY 6061 [8]

\begin{tabular}{|c|c|}
\hline Melting point $\left({ }^{\circ} \mathrm{C}\right)$ & 720 \\
\hline Density $\left(\mathrm{g} / \mathrm{cm}^{3}\right)$ & 2.7 \\
\hline Linear thermal expansion $\left(\mathrm{k}^{-1}\right)$ & $2.32 * 10^{-5}$ \\
\hline Poisson ratio & 0.33 \\
\hline Modulus of elasticity $(\mathrm{GPa})$ & 68.9 \\
\hline Thermal Conductivity $(\mathrm{W} / \mathrm{mK})$ & $151-202$ \\
\hline
\end{tabular}

The major advantages of Hybrid Matrix Composites are: -

1. High specific strength

2. High speed stiffness

3. Higher elevated temperature strength

4. Improved wear resistance

5. Low density

6. High strength to weight ratio

7. Improved damping capabilities
8. High thermal expansion coefficients

9. Good corrosion resistance etc.

TABLE 2

COMPARATIVE ANALYSIS OF DIFFERENT TECHNIQUE [9]

\begin{tabular}{|c|c|c|c|c|}
\hline Method & $\begin{array}{l}\text { Range of } \\
\text { shape and } \\
\text { size }\end{array}$ & $\begin{array}{l}\text { Range of } \\
\text { volume } \\
\text { fraction }\end{array}$ & $\begin{array}{l}\text { Damage to } \\
\text { reinforcement }\end{array}$ & Cost \\
\hline Stir casting & $\begin{array}{c}\text { Wide } \\
\text { range of } \\
\text { shapes, } \\
\text { larger size } \\
\text { up to } 500 \\
\mathrm{Kg}\end{array}$ & Up to 0.3 & No damage & $\begin{array}{c}\text { Least } \\
\text { expensive }\end{array}$ \\
\hline $\begin{array}{l}\text { Squeeze } \\
\text { casting }\end{array}$ & $\begin{array}{l}\text { Limited by } \\
\text { perform } \\
\text { shape up to } \\
2 \mathrm{~cm} \\
\text { height }\end{array}$ & $\mathrm{Up}$ to 0.5 & $\begin{array}{l}\text { Severe } \\
\text { damage }\end{array}$ & $\begin{array}{l}\text { Moderate } \\
\text { expensive }\end{array}$ \\
\hline $\begin{array}{c}\text { Powder } \\
\text { metallurgy }\end{array}$ & $\begin{array}{c}\text { Wide } \\
\text { range, } \\
\text { restricted } \\
\text { size }\end{array}$ & & $\begin{array}{c}\text { Reinforcement } \\
\text { fracture }\end{array}$ & Expensive \\
\hline $\begin{array}{l}\text { Spray } \\
\text { casting }\end{array}$ & $\begin{array}{c}\text { Limited } \\
\text { shape, } \\
\text { large shape }\end{array}$ & $0.3-0.7$ & & Expensive \\
\hline
\end{tabular}

II. REINFORCEMENT IN AMCS

The mechanical characterization of AMC's are enhanced by the reinforcement and its main function to bear the load [10]. There are two main types of the reinforcement in AMCs. They are continuous and discontinuous [11]. Continuous reinforcement used fibers in the form of 'SiC' or mainly ceramic [12]. Where as in the case of discontinues reinforcement used whiskers [13] 'SiC'. Al2O3, Gr and B4C are used for wide spread reinforcement which are inexpensive industrial abrasives which provides good mechanical and wear confrontation which are having the high stiffness value [14].

\section{A. Classification of Reinforcements}

a) Particle reinforced composites

b) Finer reinforced composites

It by and large contain equiaxed ceramic reinforcements, fundamentally oxides (for example alumina, A12O3), carbides for example Silicon carbide, $\mathrm{SiC}$ ) or borides (for example titanium bromide, TiB2), with 
a viewpoint proportion under $5 \%$ and volume division is under $30 \%$. They can be delivered by the ceramic powders, trailed by liquid - metamethods, for example, stir casting, squeeze infiltration and in situ processes.

These contain either somewhat fine consistent fibers, normally of $\mathrm{Al} 2 \mathrm{O} 3, \mathrm{SiC}$, or carbon, with a distance across beneath $20 \mu \mathrm{m}$, or coarser filaments or monofilaments. Mono fibers are huge distances across $(100-50 \mu \mathrm{m})$ filaments, for the most part, created by chemical vapor deposition (CVD) of either Si C or boron (B) into a center of carbon fiber or tungsten (W).

\section{B. Multifarious reinforcements in AMMCs}

Aluminum metal matrix composites give two factors like high explicit strength and lower thickness. As the properties, for example, wear obstruction, hardness, solidness, and durability, these aluminum lattices are to be implanted with harder particles to accomplish the above properties to the most extreme degree.

Different oxides, carbides, nitrides, and borides in the structure such as $\mathrm{SiC}, \mathrm{Al} 2 \mathrm{O} 3, \mathrm{~B} 4 \mathrm{C}, \mathrm{TiC}, \mathrm{TiB} 2, \mathrm{TiO} 2, \mathrm{AIN}$, $\mathrm{BN}$, and $\mathrm{Si} 3 \mathrm{~N} 4$ can be built up in the aluminium lattice to gain these qualities. The mechanical properties are influenced by the volume portion, size, shape, and spatial dispersion of the support, as well as the remotely applied burden moved to the support particles. The mechanical properties of the molecule-supported aluminium metal grid composite outperform those of the unreinforced one. However, the mechanical properties of the fibre or bristlesupported composite outperform those of the moleculebuilt-up AMMCs. Earthenware support levels are 30\% and $70 \%$ for underlying applications and electronic bundling apps, respectively.

\section{Production in AluminiUm MAtrix HybRid COMPOSITES}

In the production of hybrid AMC's, powder metrology plays a crucial role in the process. The composites which are having more volume of the reinforced particulars can be produced by this technique [15]. Depending upon the factors such as simplicity, flexibility and commercial viability; stir casting process remained the most investigated technique for fabricating AMC's (See Table 2) $[16,17]$ Clustering and particle segregation and to form secondary phase have been widely reported [17, 18]. The performance of the composites is then determined by an interfacial response and secondary phase development. The interfacial reaction can be avoided by using reinforcing elements such as alumina and boron carbide [19]. Cold deformation and hot isostatic pressure were used to minimise porosity in cast AMCs [20,21].

Mazaheri introduced friction stir processing as a revolutionary way for generating surface metal matrix composites [22] metal matrix composites generated using the powder metallurgy and stir casting processes in order to boost strength and stiffness, ductility and toughness [23, $24]$.

TABLE 3

SUM PROVEN APPLICATION OF ALUMINIUM MATRIX COMPOSITES [25]

\begin{tabular}{|c|c|c|}
\hline Manufacture & Composite & Component \\
\hline $\begin{array}{c}\text { Duralcan, Martin } \\
\text { Marietta }\end{array}$ & $\mathrm{Al} / \mathrm{SiCp}$ & Pistons \\
\hline Duralcan, lanxide & $\mathrm{Al} / \mathrm{SiCp}$ & Brake rotors \\
\hline Nissan & $\mathrm{Al} / \mathrm{SiCw}$ & Connecting rod \\
\hline Toyota & $\mathrm{Al} / \mathrm{Al}_{2} \mathrm{O}_{3}$ & Piston rings \\
\hline Honda & $\mathrm{Al} / \mathrm{Al}_{2} \mathrm{O}_{3}$ & Connecting rod \\
\hline $\mathrm{GM}$ & $\mathrm{Al} / \mathrm{SiCp}$ & $\begin{array}{c}\text { Rear brake drum, } \\
\text { drive shaft, and } \\
\text { engine cradle }\end{array}$ \\
\hline
\end{tabular}

\section{MECHANICAL PROPERTIES OF AMMCS}

The mechanical properties of ALUMINIUM METAL MATRIX COMPOSITES are: -

1) Tensile strength

2) Impact strength

3) hardness

4) compression strength

5) corrosion

6) fatigue behaviour

\section{APPLICATIONS OF AL MMCS IN VARIOUS INDUSTRY}

\section{A. Automotive industry}

In the automobile business, aluminium metal matrix composites are in high demand. Through research and 
development, lighter, designed materials that outperform current materials are being developed. In the immediate term, steel and cast iron substitution in internal combustion engine applications, as well as unspring weight components such as the brake system, are thought the most promising.

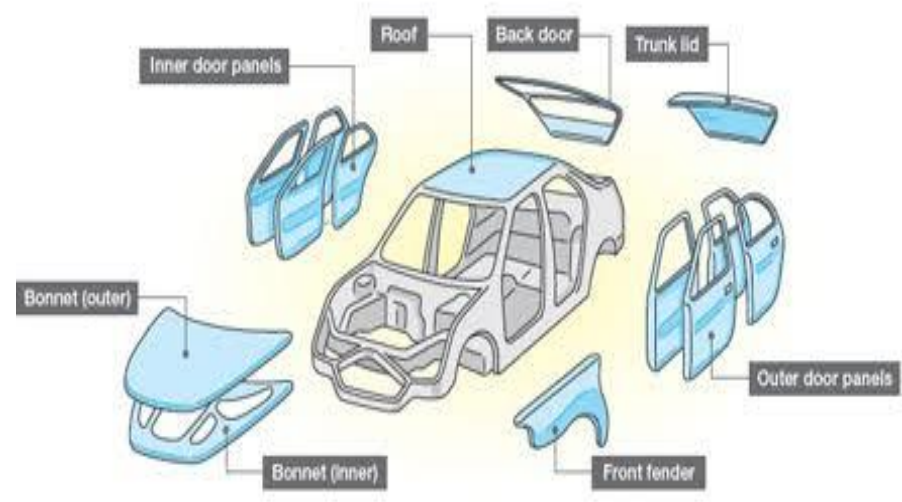

Fig.1 Alloy sheet for body panels features [26]

Aluminum metal framework composites are reasonable substitutions, for steel as well as for aluminum amalgams in different auto frameworks and parts (See Fig.1). There are numerous ways of accomplishing lightweight without compromising the strength and security prerequisites. Preferably, it is generally expected practice to totally supplant the current primary material with the material of better return strength, with a potential decrease in area aspects. The alternate method of accomplishing weight saving is to specifically supplant traditional steel at explicit regions with lighter materials. By applying the mass decrease methods, the mass of vehicles can be diminished autonomous of vehicle size, usefulness, class, or model [27].

The auto-breaking framework parts, for example, the plate brakes and calipers, are another region where critical weight investment funds can be acknowledged by using $\mathrm{Al}$ MMCs (See Table 3). Most chamber heads are aluminumbased, and by 2005, motor squares produced using aluminum in the US light-obligation vehicles passed the 50 $\%$ mark, outperforming steel around here interestingly [28] Aluminum combinations and composites are likewise contending to supplant numerous different customary steel parts in vehicles, for example, valve covers, force converter and transmission lodgings, crankcase, control arms, supports, suspension joins, entryway outlines, directing wheels, dashboards, sheet board sand radiates are additionally being supplanted by compound aluminum amalgams and composites (See Fig.2) [29]. New regions are being investigated for aluminum-based materials, and these incorporate "all-aluminum" bodies, guards, crash the executive's frameworks, and unibody development [30].

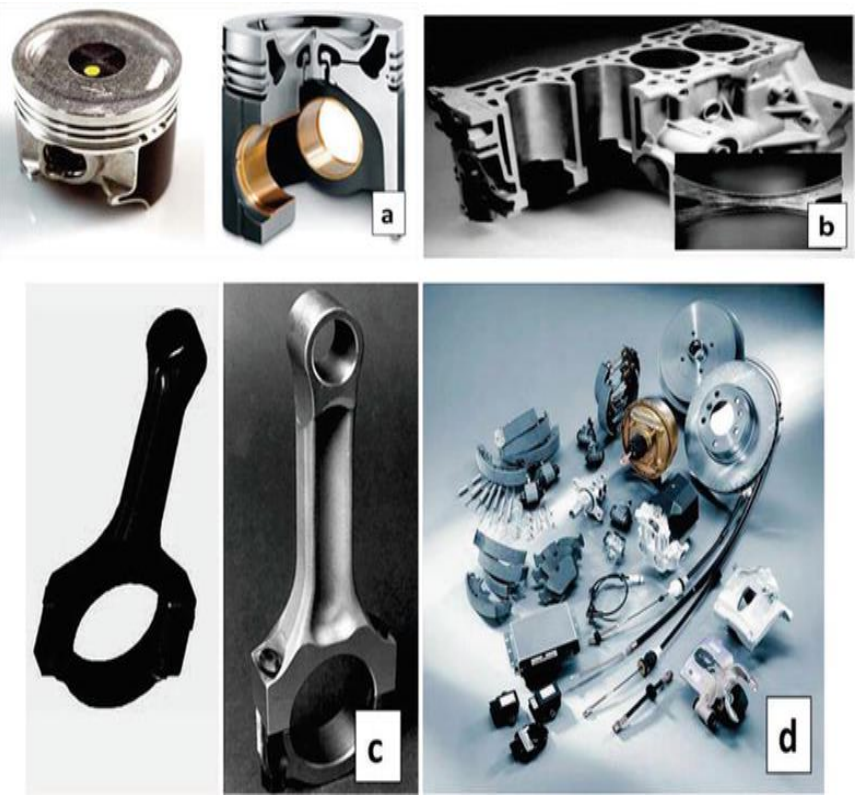

Fig.2 (a) A piston, (b) an engine with a cylinder barrel, (c) a piston connecting rod, and $(\mathrm{d})$ a brake system built of aluminium $(\mathrm{Al})$ metal matrix composites (MMCs) [31]

\section{B. Aerospace and aircraft manufacturing}

Aluminium metal matrix composites have been employed in space construction materials. For example, on October 4, 1957, Sputnik1 was launched (See Fig.3). Aluminium metal is selected because of its light weight and ability to endure the forces that occur during space launch and operation. Aluminium metal matrix composites are utilised in the Apollo spacecraft, Skylab, space shuttles, and the International Space Station. Aluminium alloys/composites consistently outperform other metals in mechanical stability, damping, thermal management, and weight reduction [32].

\section{Rail transport}

Planning with aluminum brings about light-weight vehicles that hold the strength of steel vehicles however can convey more noteworthy burdens, henceforth setting 
aside cash in expanded cargo and decreased fuel costs. The third era of the French TGV Duplex rapid train is a genuine model for this situation. The train changed over from steel to aluminum-based materials, bringing about a $20 \%$ weight saving, while simultaneously changing over to two decks and keeping the pivoting load under 17 tons. Additionally, the Japanese fast "projectile" train and the Washington DC Metro trains are likewise made with aluminum-based materials.

The sturdiness of aluminum makes it a reasonable material for the rail street climate. Broad shaking tests and many years of utilization offer declaration to aluminum's prevalence for this application. A new report shows that following 20 years of administration, there is an irrelevant loss of metal thickness or surface imperfections on vehicles used to send various materials a normal of 110,000 miles each year. Metal misfortune on floors and sidewalls from consumption and wear estimated around $25 \%$ not exactly similar steel vehicles [34].

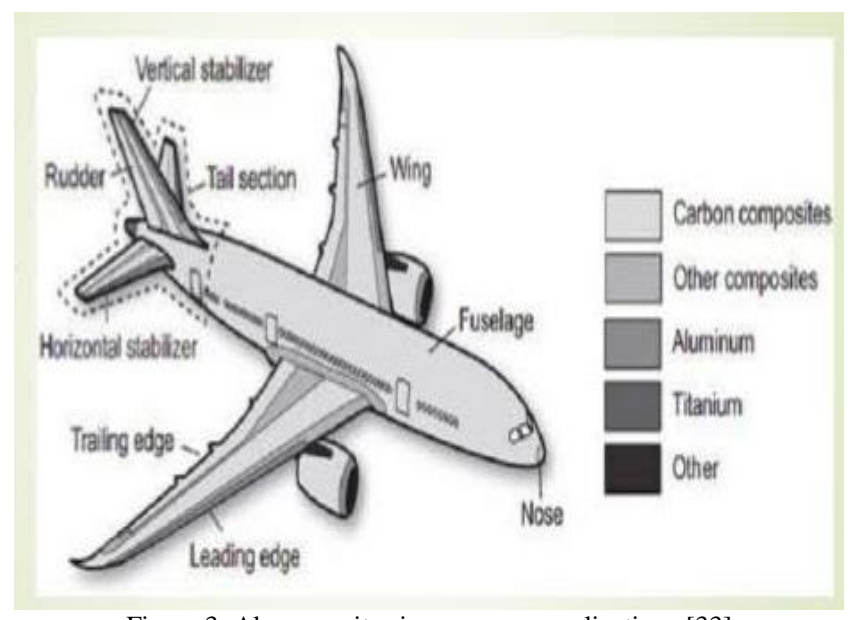

Figure 3. Al composites in aerospace applications [33]

\section{Transport via sea}

Aluminium alloys and composites have also been used in the production of marine transport. The material used to improve the speed and size of boats, yachts, ferries, and ships while also enhancing fuel efficiency, seaworthiness, safety, and reliability and lowering maintenance costs. Weight savings of 35-45 percent in hulls and 55-65 percent in superstructures can be realised by substituting aluminium for steel [34]. Increased vessel speeds and cargo capabilities result in increased traffic volume and profitability for a ship or boat operator.

\section{CONCLUSION}

Al MMCs presents an incredible open door and a large group of opportunities for the materials/plan engineer. There are currently numerous opportunities for control of properties/property mixes to suit explicit necessities of material and part properties to upgrade execution and dependability. New and arising mechanical advancements highlight the increment use of Al MMCs in current and future modern turns of events. A portion of the current obstructions and difficulties are being addressed through different $\mathrm{R} \& \mathrm{D}$ endeavors to track down an enduring arrangement.

From the front-going survey, it is clear that the eventual fate of $\mathrm{Al} \mathrm{MMCs}$ in different modern and business applications is exceptionally splendid. Progressed innovative improvements in essential and auxiliary handling of $\mathrm{Al}$ MMCs will keep on giving them a strategic advantage over the elective materials like $\mathrm{Mg}$, AHSS, and polymer composites. The principal difficulties and hindrances that have been recognized incorporate the absence of property displaying (particularly the hightemperature conduct of $\mathrm{Al} \mathrm{MMCs}$ ), absence of plan information, and significant expenses of essential and optional cycles. Be that as it may, there are promising indications of innovative forward leaps by different examination endeavors committed to tracking down answers for these difficulties. New advancements in CNT and nanotechnology have, for instance, offered conceivable outcomes of the creation of Al MMCs with upgraded properties for high-temperature applications and further developed wear and erosion obstruction. Different improvements, for example, the novel rheocasting cycle of semi-strong composites [e.g., see [35] and FGM scoop so offered additional opportunities of cost decrease in essential creation and auxiliary handling of $\mathrm{Al}$ MMCs, individually. New composites of aluminum have been created for application in such regions as crash the board 
(crash combination) - a region recently overwhelmed by steel. These composites offer new R\&D openings for additional improvement of $\mathrm{Al} \mathrm{MMCs}$ and will reclassify new jobs and capabilities of Al MMCs in auto applications. Different analysts are additionally thinking of inventive expense decrease strategies to cut down the expense of supplanting regular ferrous materials with aluminum metal matrix composites.

Author declare that there is no any conflict of interest

\section{REFERENCES}

[1] Sie-Chin Tjong. "Processing and Deformation Characteristics of Metals Reinforced with Ceramic Nanoparticles". Nanocrystalline materials. Pages 269-304. Edition 2nd ed. https://doi.org/10.1016/B978-0-12-407796-6.00008-7

[2] Sumit Kumar Tiwari, Sanjay Soni, R S Rana, Alok Singh, "Effect of Heat Treatment on Mechanical Properties of Aluminium alloy - Fly ash Metal Matrix Composite", 5th International Conference of Materials Processing and Characterization (ICMPC 2016), Proceedings 4 (2017), 3458-3465.

[3] I.A, Alkadir and L.S. Salim, "Effect of B4ClFly Ash Addition on Wear and Mechanical Properties of $\mathrm{Al}-\mathrm{Cu}-\mathrm{Mg}$ Alloy,” Engineering and Technology Journal, Vol. 35, Part A. No. 4, pp. 301-310, 2017.

[4] Syed Nasimul. Alam and Lailesh Kumar, "Mechanical Properties of Aluminium Based Metal Matrix Composites Reinforced with Graphite Nano platelets”, Materials Science \& Engineering A, Volume 667, 14 June 2016, Pages 16-32. https://doi.org/10.1016/j.msea.2016.04.054

[5] Mina Bastwros, Gap-Yong Kim, Can Zhu, Kun Zhang, Shiren Wang, Xiaoduan Tang, Xinwei Wang, "Effect of ball milling on graphene reinforced Al6061 composite fabricated by semi-solid sintering”, Composites: Part B 60 (2014) 111118. https://doi.org/10.1016/j.compositesb.2013.12.043

[6] S. Gopalakrishnan, N. Murugan, "Production and wear characterisation of AA 6061 matrix titanium carbide particulate reinforced composite by enhanced stir casting method", Composites: Part B 43 (2012) 302-308. https://doi.org/10.1016/j.compositesb.2011.08.049

[7] J. Allwyn Kingsly Gladston, I. Dinaharan, N. Mohamed Sheriff, J. David Raja Selvam, "Dry sliding wear behavior of AA6061 aluminum alloy composites reinforced rice husk ash particulates produced using compo casting", Journal of Asian
Ceramic Societies Volume 5, Issue 2, June 2017, Pages 127 135 (2017). https://doi.org/10.1016/j.jascer.2017.03.005

[8] G. B. Veeresh Kumar, C. S. P. Rao, N. Selvaraj, M. S. Bhagyashekar, "Studies on Al6061-SiC and Al7075-Al2O3 Metal Matrix Composites". Journal of Minerals and Materials Characterization and Engineering, Vol. 9, No.1, pp.43-55, 2010. http://dx.doi.org/10.4236/jmmce.2010.91004

[9] Tamer Ozben, Erol Kilickap, Orhan Cakır, "Investigation of mechanical and machinability propertiesof $\mathrm{SiC}$ particle reinforced Al-MMC", Journal of Materials Processing Technology 198(1-3):220-225, March 2008.

https://doi.org/10.1016/j.jmatprotec.2007.06.082

[10] Diler E A and Ipek R. "Main and interaction effects of matrix particle size, reinforcement particle size and volume fraction on wear characteristics of $\mathrm{Al}-\mathrm{SiCp}$ composites using central composite design”. Composites Part B: Engineering. Volume 50, July 2013, Pages 371-380.

[11] Natrayan L., Senthil Kumar M., "Study on Squeeze Casting of Aluminum Matrix Composites-A Review". In: Antony K., Davim J. (eds) Advanced Manufacturing and Materials Science. Lecture Notes on Multidisciplinary Industrial Engineering. Springer, Cham. https://doi.org/10.1007/978-3-319-76276-0_8

[12] Pei W, Eckert J, Prashanth K-K, Wu M W, Kaban I, Xi L-X and Scundino S. "A comprehensive review of aluminium matrix composite reinforcement and fabrication methodologies". Functional Composites and Structures, Volume 3, Number 1.

[13] Luster, J. W., Thumann, M., Baumann, R. "Mechanical properties of aluminium alloy 6061-Al 2 O 3 composites". Materials Science and Technology1993 / 10 Vol. 9; Iss. 10

[14] Chen F, Gupta N, Behera RK, Rohatgi PK. "GrapheneReinforced Aluminum Matrix Composites: A Review of Synthesis Methods and Properties” JOM. 70: 837-845. https://doi.org/10.1007/S11837-018-2810-7

[15] D. B. Miracle, "Metal Matrix Composites-From Science to Technological Significance," Composite Science Technology, Vol. 65, No. 15-16, 2005, pp. 2526-2540. http://dx.doi.org/10.1016/j.compscitech.2005.05.027

[16] Kaczmar JW, PietrzakK, WłosinskiW. "The production and application of metal matrix composite materials". J Mater Process Technol 2000; 106 (1-3):58-67.

[17] Rohatgi, P. "Cast aluminum-matrix composites for automotive applications". JOM 43, 10-15 (1991). https://doi.org/10.1007/BF03220538 
[18] Ravi KR ,Sreekumar VM, Pillai RM, Mahato C, Amaranathan KR,Arulkumar R, etal. "Optimization of mixing parameters througha water model for metal matrix composites synthesis". Mater Des 2007;28(3):871-81. https://doi.org/10.1016/j.matdes.2005.10.007

[19] Zulfia A, Atkinson HV, Jones H, King S. "Effect of hot isostatic pressing on cast A357 aluminium alloy with and without SiC particle reinforcement”. J Mater Sci 1999;34(17):4305-10.

[20] Alaneme KK. "Mechanical behaviour of cold deformed and solution heat-treated alumina reinforced AA6063 metal matrix composites". West Indian J Eng 2013; 35 (2):31-5.

[21] MazaheriY, Karimzadeh F, Enayati M H. "A novel technique for development of $\mathrm{A} 356 / \mathrm{Al} 2 \mathrm{O} 3$ surface nano composite by friction stir processing”. J Mater Process Technol 2011; $211 \quad$ (10): $1614-9$. https://doi.org/10.1016/j.jmatprotec.2011.04.015

[22] Dharmpal D, Ripandeep SS. "Preparation of surface composite by friction stir processing and its mechanical characterization”. Int J Mech Eng2013; 3 (1).

[23] Akinlabi ET, Mahamood RM, Akinlabi SA, Ogunmuyiwa E. "Processing parameters influence on wear resistance behaviour of friction stir processed Al-TiC composites". Adv Mater Sci Eng 2014; 2014: e724590. https://doi.org/10.1155/2014/724590

[24] K. M. Shorowordi, T. Laoui, A. S. M. A. Haseeb, J. P. Celis and L. Froyen, "Microstructure and Interface Characteristics of B4C, SiC and Al2O3 Reinforced Al Matrix Composites: A Comparative Study," Journal of Material Processing Technology, Vol. 142, No. 3, 2003, pp. 738-743. http://dx.doi.org/10.1016/S0924-0136(03)00815-X

[25] Jiang Rui-song, Wang Wen-hu, Song Guo-dong, Wang Zeng-qiang, "Experimental investigation on machinability of in situ formed TiB2particles reinforced Al MMCs", Journal of Manufacturing Process. Volume 23, August 2016, Pages 249-257. http://dx.doi.org/10.1016\%2Fj.jmapro.2016.05.004

[26] [26] UACJ. “A major global aluminum group, including company strengths, messages from management, management philosophy and company overview". https://www.uacj.co.jp/english/products/sheeting/aas$\underline{\text { anel.htm }}$

[27] Nturanabo F, Masu LM, Govender G. "Automotive lightweighting using aluminium metal matrix composites". In: Materials Science Forum Aug 1, 2015. Vol. 828. Switzerland: Trans Tech Publications Ltd; 2015. p. 485
[28] Simpson J. "Aluminum advances: Aluminum passes iron among automotive materials in use worldwide; what lies ahead? Aluminum Now. 2006.

[29] Caceres CH. "Economical and environmental factors in light alloys: Automotive applications”. Metallurgical and Material Transactions A. 2007; 38(A):1649-1662interface characteristics of $\mathrm{B} 4 \mathrm{C}, \mathrm{SiC}$.

[30] Muneer S, Khairul AI. "Forecasting of global automotive industry-key trends in passenger vehicles". ARPN Journal of Engineering and Applied Sciences. Sep 2015; 10 (17):7830-7834

[31] Vikas Verma and Alexandra Khvan (April 19th 2019). "A Short Review on Al MMC with Reinforcement Addition Effect on Their Mechanical and Wear Behaviour", Advances in Composite Materials Development, Dumitra Lucan, Intech Open, https://doi.org/10.5772/intechopen.83584

[32] Finckenor MM. "Materials for Spacecraft. Alabama: NASA, Marshall Space Flight Center”. August 1, 2018. https://dx.doi.org/doi:10.2514/4.104893

[33] Metal Matrix Composites, https://www.slideshare.net/NikhilDixit28/metal-matrixcomposites-mmc

[34] The Aluminum Association. Product markets. Available from: https://www.aluminum.org/productmarkets/other$\underline{\text { market }}$

[35] Ivanchev L, Wilkins D, Govender S, Du Preez W, Bean R. Rheo-processing of semi-solid alloys: "A new technology for manufacturing automotive and aerospace components". South African Journal of Science. Aug 2008; 104 (7-8):257259. 